\title{
Entrepreneurial learning and innovation: qualitative evidence from agri-business technology-based small firms in New Zealand
}

\author{
David Deakins* \\ Department of Entrepreneurship, Innovation and Strategy, \\ Lancaster University Management School, \\ Lancaster University, \\ Lancaster, LA1 4YX, UK \\ Email: d.deakins@lancaster.ac.uk \\ *Corresponding author
}

\section{Jo Bensemann}

School of Management, Massey University, Palmerston North 4442, New Zealand

Email: j.bensemann@massey.ac.z

\begin{abstract}
The focus of this paper is on the nexus between entrepreneurial learning and the innovation process. In particular, the role that entrepreneurial learning plays in the innovation process. We have collected qualitative interview evidence with a sample of 30 technology-based small firms (TBSFs) engaged in the innovation process. TBSFs are highly diverse, defying consistent definitions, and operate across different sectors, but our sample is drawn solely from the agri-business sector within the unique environment of New Zealand. The literature on entrepreneurial learning is now well established and has identified the importance of both individual entrepreneurial learning and organisational learning for the determination of dynamic capability in TBSFs. Similarly, the literature on the innovation process in small firms and TBSFs is well established indicating the expected resource constraints and challenges from theory in the innovation process for TBSFs. However, no previous research has examined the role of entrepreneurial learning in the innovation process with TBSFs. We present qualitative interview evidence that demonstrates that entrepreneurial learning has a critical role in the innovation process enabling TBSFs to overcome resource constraints and challenges in a lean contextual environment such as New Zealand.
\end{abstract}

Keywords: New Zealand; entrepreneurial learning; innovation; agri-business; technology-based small firms.

Reference to this paper should be made as follows: Deakins, D. and Bensemann, J. (xxxx) 'Entrepreneurial learning and innovation: qualitative evidence from agri-business technology-based small firms in New Zealand', Int. J. Innovation and Learning, Vol. X, No. Y, pp.000-000. 
Biographical notes: David Deakins is currently an Honorary Researcher at Lancaster University and Adjunct Professor at Massey University. He has over 30 years' experience of undertaking high quality qualitative and quantitative research with SMEs and entrepreneurs. He returned to the UK in May 2014 after a full time role at Massey University in New Zealand, holding a Chair in Small Business, and is the Former Director of the New Zealand Centre for SME Research (NZSMERC). He retired from a full time academic role at the end of January 2014.

Jo Bensemann is the Associate Head of School in the School of Management in the College of Business at Massey University, New Zealand. She teaches small business management and entrepreneurship, innovation and creativity and also contributes to Massey's MBA program.

This paper is a revised and expanded version of a paper entitled 'Entrepreneurial learning and innovation: qualitative evidence from agri-business technology-based small firms in New Zealand', presented at High Technology Small Firms' Conference, Liverpool, June 2016.

\section{Introduction}

The role of entrepreneurial learning in technology-based small firms (TBSFs) has received increased attention in entrepreneurship literature since it has been established that there is a close link between the performance of TBSFs and their ability to engage in entrepreneurial learning (Zahra and George, 2002). In this paper we focus on the nexus of entrepreneurial learning and innovation, specifically the role of entrepreneurial learning in the process of innovation within TBSFs. We adopt a broad approach to innovation (OECD, 2007), however, as will be explained later, our sample of TBSFs for this study were purposefully selected as being engaged in the innovation process through specific R\&D and prototype development with new products. We specifically set out to include TBSFs in the agri-business sectors engaged in such processes.

A resource-based view (RBV) that encompasses dynamic capabilities (Barney, 1991; Teece, 2007) would see that, in order to grow successfully, TBSFs must have the capability to undertake knowledge acquisition, assimilation and implementation through the process of entrepreneurial and organisational learning. Entrepreneurial learning can be viewed as an important component of knowledge management and influence on TBSFs' innovative capability, thus companies need to have absorptive capacity and dynamic capabilities which will determine their competitive performance.

This theoretical basis allows us to formulate the research problem as: What are the factors that affect the relationship between entrepreneurial learning and innovation? And to consider the relative importance of these different factors in the lean environmental context of New Zealand. Using the theoretical basis of RBV and dynamic capabilities, this relationship is illustrated by Figure 1 . 
Figure 1 The theoretical relationship between entrepreneurial learning and innovation (see online version for colours)

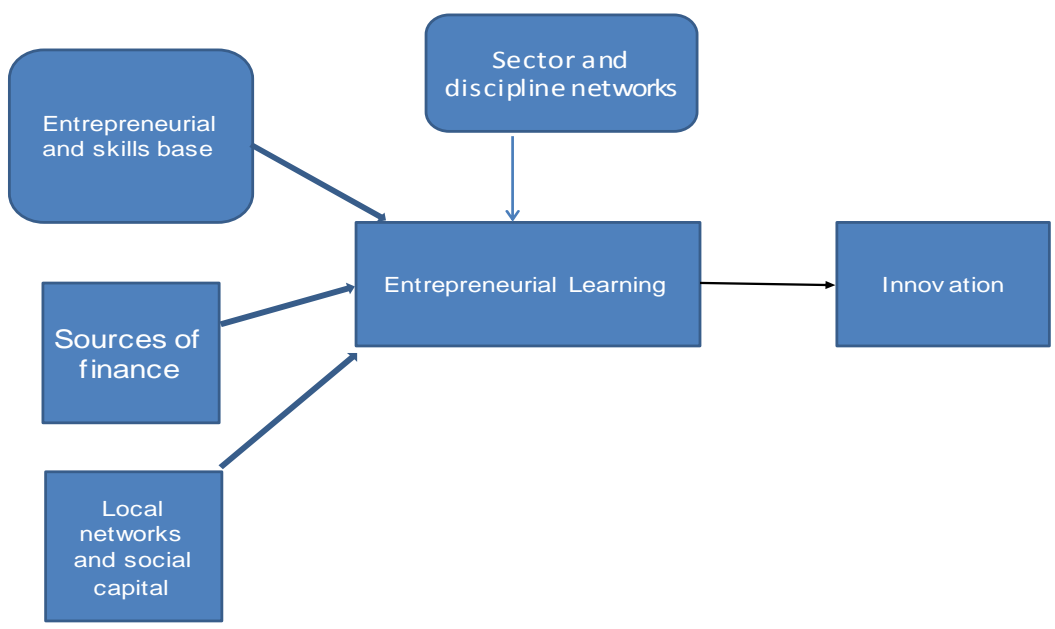

In a review paper, Wang and Chugh (2014, p.32) call for more research on the role of entrepreneurial learning in the opportunity discovery and exploitation process. This paper's contribution lies in providing qualitative evidence on the role of entrepreneurial learning in the innovation process from a program of 30 interviews with key or founding entrepreneurs in New Zealand TBSFs. We discuss the implications of our qualitative empirical evidence and suggest a conceptual framework.

Definitions of TBSFs vary in academic studies (see Buchart, 1987; Mason and Brown, 2013). This is partly because they are characterised by diversity and can vary from small firms engaged in life sciences, pharmaceutical, manufacturing to IT and software development, where the pace and type of technological development varies across a range of sectors. The distinguishing characteristic, however, is that they are engaged with new product development (NPD). In this paper, we hold the sector consistent: that of agri-business, but include a diversity of TBSFs in technology developments (see Table 1). TBSFs selected were all engaged in the process of innovation in the agri-business sector, either directly through agri-business NPD or through service provision in the sector to other agri-businesses. The aim of the paper is to understand the role of entrepreneurial learning in these diverse agri-business TBSFs as they engaged in the innovation process.

The focus on the agri-business sector ${ }^{1}$ is warranted because of its strategic importance for the New Zealand economy. It has been recognised for some time that there is also much latent potential from improving the value-added and productive potential of this strategic sector. For example, the agri-business sector is an important export earner and, although New Zealand's export earnings contribute $30 \%$ of the economy's GDP, many of New Zealand's exports from the agri-business sector are known to be low in value-added. This low value-added issue has been highlighted by an OECD paper that examined the participation of OECD nations in global value chains (GVCs). The paper by de Backer and Yamano (2012) indicated that economies with high trade/GDP ratios have greater participation in GVCs. New Zealand's ratio at 30\% was ranked 29th out of 36 OECD 
countries. The low value-added of the agri-business industry was also highlighted by a report on the sector by Corliolis for the former Ministry of Economic Development in 2012 and pointed in particular to the potential from increased exports from the food processing sector (Corliolis Report, 2012). Understanding the role of entrepreneurial learning in this context can help to address these issues.

It is arguable that New Zealand presents a unique contextual setting in which to examine entrepreneurial performance of TBSFs, it is a small and remote economy with TBSFs dependent on global markets. TBSFs have traditionally been seen as resource-constrained, particularly for example in accessing finance and recruiting appropriate skilled employees (see, for example, North et al., 2013). We can expect this issue to be more acute in a small, remote economy and lean environment such as New Zealand. It has been suggested that the neglect of contextual influences constitutes a major gap in the literature (Zahra and Wright, 2011). Therefore, our paper's contribution through the presentation of qualitative empirical evidence is enhanced by the unique context of the agri-business sector and the New Zealand economy. We discuss the theoretical approach to entrepreneurial learning and innovation through our literature review. The themes from the literature review are used to organise our discussion section and to illustrate the role of entrepreneurial learning in the innovation process.

It should be noted that we are not specifically concerned with rural small firms and notions of 'rurality'. A number of our sample of TBSFs, almost by definition, since some were engaged in food production, were in more rural locations, whereas others were in more urban areas (see Table 1). However, we do not attempt to make any distinction between the geographical or regional context of such firms as this merely adds a layer of complexity and to examine such divisions would warrant a separate paper. Although we do indeed point to the diversity demonstrated by our sample of 30 TBSFs, we wish to maintain the focus on the nexus between entrepreneurial learning and the process of innovation.

The remainder of this paper is organised in the following sections: literature review, agri-business TBSFs and the New Zealand context, research method, qualitative findings and analysis, discussion and implications.

\section{Literature review}

\subsection{Entrepreneurial learning and TBSFs}

The importance of the role of entrepreneurial learning on the innovation process in TBSFs has been recognised by a number of writers (Rae and Carswell, 2001; Corbett, 2002; Cope, 2005), particularly in the way that new opportunities, that may arise through innovation, are recognised and exploited. However, as mentioned in our introduction, in a recent review of research into the entrepreneurial learning process, there remains a call for more research to increase our understanding of the role that entrepreneurial learning plays in the innovation process (Wang and Chugh, 2014). A dynamic capabilities approach provides a theoretical lens for later discussion in our paper (Teece and Pisano, 1994). This theoretical approach postulates that the competitive advantage of firms depends upon their ability to organise and reconfigure their resources in a changing environment. Entrepreneurs of TBSFs need to be able to learn from previous experience in order to achieve the reconfiguration of their resource base to develop dynamic 
capabilities. It has been recognised that absorptive capacity can determine whether entrepreneurial learning is effective in reconfiguring resources and adapting to new opportunities and change (Zahra and George, 2002). The components of absorptive capacity have been identified by Newey and Zahra (2009) as: knowledge acquisition, assimilation, transformation and exploitation.

Literature on entrepreneurial learning has been concerned with the types of learning employed by entrepreneurs at the individual level and by the firm at the organisational level (that is with the nature of individual and organisational learning). Experiential learning, or 'learning by doing', has been the focus of a number of papers (Cope, 2003; Politis, 2005; Thorpe et al., 2006; Morris et al., 2011), reflecting the importance of entrepreneurial and firm experience in framing entrepreneurial opportunities and entrepreneurial actions. Politis and Gabrielsson (2015) found that a learning mode that is associated with exploration is positively associated with the ability to recognise a higher number of opportunities. Alternatively, exploratory learning through search procedures and 'trial and error' has also been the focus of research by writers in this field (Cope, 2011; Bingham and Davis, 2012). The influence of the entrepreneur in terms of an organisation's ability to learn has also been identified with organisational learning, even in small firms, and has been recognised as having an important role in the innovation process (Chiva et al., 2014; Wang et al., 2015). Babnik et al. (2014) confirm that knowledge management initiatives are an important source of organisational learning. Their study of work teams in two Slovenian service organisations, found that the occurrence of learning behaviour of team members is determined by task variety and significance and by people-oriented leadership. In addition, Sitko-Lutek and Jakubiak (2016) in a study of innovative companies' employees in Poland found that the diversity of learning styles and employee relationships was important for innovation and maintaining a competitive advantage, hence, supporting a resource-based view of the importance of learning and skill development in innovative companies and a dynamic capabilities approach. Finally, De Massis et al. (2012) have pointed to the importance of entrepreneurial learning with case studies of Italian high-technology start-ups, reinforcing the importance of experiential entrepreneurial learning for innovation in TBSFs.

Hence, the role of entrepreneurial learning in innovation can be considered to be a key component of TBSFs' capability to engage successfully in the innovation process, whether through R\&D, design, prototype development or the provision of NPD. How entrepreneurial learning influences the capability of TBSFs to engage successfully in the innovation process remains a research gap (Mason and Brown, 2013; Wang and Chugh, 2014). The contribution of this paper lies in providing insights into the role of entrepreneurial learning on the innovation process in TBSFs drawn exclusively from the agri-business sector.

Turning to empirical evidence, there has been little previous research on the role of innovation with TBSFs irrespective of sectors, and even less that is directly relevant for TBSFs in the agri-business sector. Taking TBSFs broadly, a theoretical approach based on RBV and its extension via dynamic capabilities sees TBSFs as predominantly resource constrained. This means that previous research has focused on whether such firms are able to acquire resources that they need to reconfigure their resource base over time and undertake the innovation process, especially to enable access to financial capital and skilled labour (North et al., 2013; Colombo and Grilli, 2010). 


\subsection{Networks, financing and the nature of research with TBSFs}

Local, regional and global networks theoretically can provide TBSFs with access to additional information, resources and assist with their capabilities to reconfigure resources, learn from previous experience and achieve competitive advantages via the innovation process. For example, writers have pointed to the importance of regional networks within a globalised economy (Davenport, 2005; Gellyneck et al., 2007; Virkkala, 2007) and to the comparative international importance of socio-technical networks (Rinnie and Fairweather, 2011). There may be advantages to be gained from collaboration and cooperation with strategic partners and links with other companies (Rudberg, 2004; Kalantaridis, 2006). Networks may facilitate access to sector knowledge bases to achieve open innovation (Aslesen and Freel, 2012). Writers have stressed the potential role of agents in networks, such as the role of regional agents that can 'unblock' access to knowledge bases (Cannarella and Piccioni, 2010). Within regional networks the role of the scientific research base has also been identified as a part of resource capability through technology transfer in the agri-business sector (Svensson et al., 2012). Dermol et al. (2013) in a study of networking centres in Slovenia, confirm that innovative networks are those that consist of firms in the same industry sector or 'discipline'. They also confirmed that the extent of innovation and cooperation is influenced by a history of cooperation.

Looking more specifically at studies on the role of innovation, few have examined specifically the role with TBSFs. In a review article, Knudson et al., (2004, p. 1330) comment on the "limited research on entrepreneurship and innovation in agricultural economics". Features that encourage entrepreneurship, such as the "thickness' of labour markets and access to networks have been examined (Helsley and Strange, 2011; Audretsch et al., 2011), although these studies are not necessarily focused on TBSFs. An alternative stream of research has explored the role of technology transfer in urban environments (Svensson et al., 2012). However, in a review article, Glaeser, et al. (2009) indicates that we still do not understand the causes of spatial disparities in technologybased entrepreneurship across different locations.

Much of this previous research has been on factors influencing the role of innovation locally, regionally and nationally, such as the quality and role of regional innovation systems, or on the role of innovation across sectors that are technology-related such as high value manufacturing. Recurring themes include access to resources, networks and markets. However, these have resulted from studies that are not confined to a specific sectoral focus. There has been no previous research that has systematically examined the role of entrepreneurial learning and innovation with TBSFs in the agri-business sector.

As discussed in the introduction, TBSFs are subject to definitional discrepancies and panel datasets are problematic and expensive to compile. Where studies do exist, they can be difficult to compare because of the difference in sampling techniques which are used. Revest and Sapio (2010) in a review of evidence on the development of TBSFs in Europe report limited studies in the UK, Italy and France. Work has been conducted in the USA (Carpenter and Peterson, 2002), but Revest and Sapio (p.7) claim that "the robustness of the results, however, is under question due to a number of methodological limitations". Revest and Sapio suggest four main findings: that European TBSFs finance new investments by relying primarily on internal funds, due to asymmetric information; that the European venture capital (VC) industry is caught up with that of US and amounts are too large to be viable for TBSFs; that alternative stock markets, such as EASDAQ, have 
proved unviable and, as a consequence, European Governments are actively involved in supporting TBSFs' needs for finance. Post GFC it is arguable that TBSFs will be even more financially constrained. North et al. (2013) study of TBSFs in the UK concluded that financial constraints prevented a substantial number from achieving their full growth potential.

Other studies with TBSFs have tended to be very selective and targeted at particular sub-groups such as samples from technology incubators and science parks, partly because of the convenience afforded by such samples. These studies confirm the importance of TBSFs for local economic development (Jones and Parry, 2011).

New Zealand is no exception to the relatively limited range of academic studies on the development of TBSFs. Case study investigations with bio-technology firms have pointed to the increased need for strategic alliances for small biotechnology firms (Ahn et al., 2010; Davenport, 2005). The increasing trend towards agglomeration might suggest that the New Zealand economy is too small and the infrastructure insufficiently developed to support strategic alliances. However, it is suggested that such strategic alliances need to be global in nature. Davenport (2005) in a study of innovative SMEs in New Zealand, has also pointed to the importance of global, rather than local networks for knowledge acquisition, implying the need for policy recognition of the diversity of knowledge acquisition sources and strategic alliances for TBSFs. From the existing literature and evidence we can expect that, in New Zealand, TBSFs are likely to be resource-constrained, short of sufficient skilled employees, they are likely to rely on internal sources for finance, although they may seek external sources, they will be in global markets and seeking to secure strategic alliances globally.

\section{Agri-business TBSFs and the New Zealand context}

In the World Bank's (2015) annual 'Doing Business' surveys, New Zealand ranks second behind only Singapore as one of the easiest nations in which 'to do business', scoring highly on the ease of regulations and on business registration. ${ }^{2}$ Federick and Monsen (2011) report GEM data that indicate that Early Entrepreneurial Activity rates as one of the highest in the GEM panel dataset. However, this benign regulatory environment has created an entrepreneurial paradox. Although New Zealand has a relatively high business formation rate by international comparisons, it has a relatively low proportion of high growth firms (Ministry of Economic Development, 2010). Shangqin et al. (2009, p.3) state that the "local environment for entrepreneurship is excellent (yet) innovatin remains a problem". A report from New Zealand's Treasury (2010) claims that whilst entrepreneurship start-up rates are high, competitive forces are relatively low (partly due to the limited size of the home market). ${ }^{3}$ Additionally, the OECD (2007) review on innovation policy in New Zealand commented that a lack of investment in business R\&D was a weakness of the innovation system in New Zealand.

As a result of such low levels of business expenditure on R\&D (BERD) commercialisation of research has been a specific policy target of the New Zealand Government. The government announced the investment of $\$ 400$ million in the establishment of Callaghan Innovation ${ }^{4}$ in January 2013 and increased incentives for businesses to undertake R\&D (through technology grants) in its budget for 2013-2014. Recently a further boost was provided through the announcement of a further $\$ 400 \mathrm{~m}$ 
(NZD) for science and innovation in the New Zealand Government's annual budget statement (Minister Bill English, 2016). Although BERD has improved in recent years, it still lags behind that of other OECD countries (Statistics New Zealand, 2013).

For sources of external equity, as might be expected for a small economy, New Zealand has historically had limited sources of both $\mathrm{VC}$ and business angel investment, although there are signs of improvement, these are outlined below. The start-up VC market was stated as being in a fledgling state in 2011 by a New Zealand Venture Investment Fund report [NVIF, (2011), p.4]:"The early stage company investment market in New Zealand is still in a fledgling state but has made significant progress in the last 10 years". During the post GFC period, private equity markets have seen some developments. For example, a growing interest in business angel activity has led to the creation of the Angel Association (2014) for New Zealand that aims to: "increase the quantity, quality and success of angel investments in New Zealand and in doing so create a greater pool of capital for innovative start-up companies"). Sources of VC funds are represented through the New Zealand Venture Capital Association (NZVCA, 2014) which has been longer established, but has also raised its profile and seeks to provide: "a world-best private equity and venture capital environment for the benefit of investors and entrepreneurs in New Zealand". However, although sources of external equity for TBSFs in the post GFC period could be considered to have seen some developments, they are still acknowledged to be limited and immature, hence the New Zealand Government has intervened directly through the provision of technology funding grants that have gradually been enhanced and extended. For example, the current New Zealand Government has introduced a range of measures, including R\&D grants, technology vouchers and tax cuts, targeted at raising business levels of BERD (Key, 2010). At the centre of these recent measures, the technology transfer vouchers have been targeted at technology transfer particularly aimed at trying to improve spin-out commercialisation from New Zealand's HEIs and Crown Research Institutes (CRIs). During 2011 and 2012, the threshold levels for these schemes were reduced making vouchers and grants available for smaller TBSFs, this being coupled with the announcement of the funding, mentioned earlier, and further funding, reported earlier, in 2016.

\section{Research method}

A qualitative lens was employed, this qualitative approach was appropriate because our objectives were to understand the role of entrepreneurial learning in the process of innovation and the perceptions of the entrepreneurs within the subject community (entrepreneurs of TBSFs) (McKeever et al., 2015). This qualitative interview approach also provided a way of locating the issues in context, both conceptually and empirically. To achieve this we used theory (based on the literature) as the framework for asking the questions and we went beyond description to seek explanations about factors affecting the role of entrepreneurial learning and the variety of responses to this from the respondents in our study.

Our sampling was purposeful (Gartner and Birley, 2002), with 30 principal respondents from TBSFs in the agri-business sector. These respondents provided the empirical data for our qualitative analysis. Our sample comprised TBSF entrepreneurs known to be actively engaged in technological developments in the agri-business sector. Some were identified from local knowledge and from contact with local business 
development organisations and the presence of the researchers in the various communities allowed identification of additional respondents through snowball sampling. The choice of new respondents was driven primarily by what they might contribute to the emerging theory (Alvesson and Skoldberg, 2000; McKeever et al., 2015). For additional background to our case we also interviewed a further nine key informants. They were representatives of agencies working closely with our entrepreneur respondents and also acted as gatekeepers in this research study which ensured validity and purpose of the study with the main respondents.

A qualitative in-depth interview program was undertaken with $30^{5}$ in-depth, face to face interviews with respondents from very diverse TBSFs, but consistently all in the agri-business sector and all known to be engaged in the innovation process, see Table 1 for detail. The interviews with respondents were conducted using an open-ended interview guide which was used to investigate the role of factors affecting entrepreneurial learning in the context of issues and challenges faced by the respondents engaged in the innovation process. The interviews were loosely structured, starting with broad questions about the respondent's business and innovative activity, with subsequent questions arising through dialogue between the researcher and respondent. It was important for the interviews to be sufficiently open-ended to allow for the exploration of additional themes from the data. The nine interviews with key respondents were used to provide thick description (Geertz, 1973; McKelvey, 2004; Jack, 2005, McKeever et al., 2015) and a general picture of the agri-business and technology environment. The research approach allowed for significant patterns to emerge as they cut across multiple experiences of respondents (Patton, 2002). Low risk ethical approval was obtained from Massey University's Human Ethics Committee and interview respondents were offered the opportunity to review the transcripts and make subsequent changes before analysis of anonymised transcripts was undertaken.

The interviews ranged between one and two hours and were recorded and transcribed verbatim. Besides the notes taken during the interviews, an expanded account was made within four hours, to fill in details and to recall things that were not recorded on the spot. The authors met to discuss these experiences and recordings, forming an introspective record of field work, enabling the authors to take into account personal biases and feelings, and to understand their influence on the research (Emerson et al., 1995; Salvato and Corbetta, 2013).

\section{Data analysis}

As is typical in inductive interview-based research (Miles and Huberman, 1994), we analysed the data by first building individual summaries, synthesizing and comparing the interview transcripts and our field notes collected after the interviews. Analysis was undertaken with QSR Nvivo qualitative data analysis software, utilising nodes derived from theory, but also allowing new codes and nodes to be established from the data. Respondents were offered the opportunity to review the transcripts and make subsequent corrections before analysis of anonymised transcripts was undertaken. Although a number of firms could be described as mature, in a small number of cases this maturity comprised a period of non-technological development as they were still engaged in R\&D for new products. ${ }^{6}$ 
Table 1 Agri-business TBSFs profile data

\begin{tabular}{|c|c|c|c|}
\hline TBSF & Agri-business sub-sector & FTES & Respondent \\
\hline \#01 & Agricultural eqpt (mftr) & 16 & $\mathrm{FE}$ \\
\hline$\# 02$ & Agricultural eqpt (mftr) & 30 & $\mathrm{FE}$ \\
\hline$\# 03$ & Fertiliser solutions & 25 & FE \\
\hline \#04 & Agricultural eqpt (mftr) & 1 & $\mathrm{FE}$ \\
\hline$\# 05$ & Software and farm mgt & 3 & $\mathrm{FE}$ \\
\hline \#06 & Software and fin mgt & 30 & FM \\
\hline$\# 07$ & Large earthmoving eqpt (mftr) & 65 & NPD \\
\hline \#08 & Dairy farming eqpt (mftr) & 12 & MD \\
\hline$\# 09$ & Agricultural engineering & 43 & $\mathrm{FE}$ \\
\hline$\# 10$ & Farm eqpt (mftr) & 20 & FE \\
\hline \#11 & Dairy farming eqpt & 3 & $\mathrm{FE}$ \\
\hline$\# 12$ & Flax and oil processing & 8 & FE \\
\hline$\# 13$ & Farm services & 7 & FE \\
\hline \#14 & Remote telemetry & 18 & $\mathrm{FE}$ \\
\hline \#15 & Fertiliser and seeds & 12 & $\mathrm{FE}$ \\
\hline \#16 & Aborculture & 3 & FE \\
\hline \#17 & Biotech & 4 & FE \\
\hline \#18 & Vanilla processing & 3 & FE \\
\hline \#19 & Biotech & 6 & $\mathrm{FE}$ \\
\hline$\# 20$ & Remote monitoring & 8 & NPD \\
\hline \#21 & Mowing equipment (mftr) & 25 & GM \\
\hline$\# 22$ & Aerial photography & 18 & MD \\
\hline$\# 23$ & Bio-based application & 2 & FE \\
\hline \#24 & Water technology (mftr) & 31 & MD \\
\hline \#25 & Effluent control & 4 & FE \\
\hline \#26 & Hydrophonic systems & 9 & MD \\
\hline \#27 & Animal tags (mftr) & 80 & FE \\
\hline \#28 & Engineering systems (mftr) & 35 & NPD \\
\hline \#29 & Fruit producer & 9 & FE \\
\hline$\# 30$ & Biotech & 11 & $\mathrm{FE}$ \\
\hline
\end{tabular}

Note: FE: founding entrepreneur(s), NPD: new product development manager; MD: managing director; FM: finance manager.

The diversity of the large amount of qualitative data from the 30 companies interviewed was reconciled in two ways. First by combining data against the theoretical themes, which formed Nvivo nodes, as explained in the previous paragraph. Second, through allowing themes to emerge independently from the data and from cases. For example, these included case themes such as bootstrapping and bricolage. Cross referencing was undertaken to ensure that cases were consistent in networks of theoretical themes, using the model illustrated by Figure 1. 


\title{
6 Findings and analysis
}

Adopting our theoretical lens of dynamic capabilities and absorptive capacity, we examine how agri-business TBSFs learn to improve entrepreneurial capability in the innovation process. In this section, we discuss emergent themes that emerged from our qualitative analysis, these themes are identified with the sub-headings (in italics) in this section. As one of these themes, we note the rapid change associated with the levels of growth required for all the TBSFs. This is illustrative of the context in which entrepreneurial learning develops.

\subsection{Innovation: achieving growth and dealing with change}

The innovation process in TBSFs can put pressure on resources, which can require a fundamental change in organisation, management and often the entrepreneurial team. The role of entrepreneurial learning can enable sustained innovation, but this involves change and growth. The following comment from case \#09, a long established company exploiting new opportunities from the innovation process, is representative:

“There's been a fundamental change, I've been here 3 years and we've grown about $40 \%$ over that 3-year period." \#09

Entrepreneurial learning, as represented by organisational learning, facilitates change. The growth and change process, in long established companies, can put pressure on staff culture and comfort levels which can lead to some initial resistance. For example, in case \#24, a long-established manufacturing company, that has achieved a growth in FTEs from nine to 31 over the past 13 years, the respondent commented on the change in culture required as a result of this:

\begin{abstract}
"One of the questions I get asked by not just the senior team but the rest of the staff when we go into the plan for the year is why do we have to keep growing, and I said because long term in any industry if you are making -----, you would have 100 competitors jumping in ------. We can't afford to stand still." \#24
\end{abstract}

Entrepreneurial learning, as represented by individual learning, facilitated dealing with growth in younger TBSFs. For companies that were more recent start-ups, a rapid early growth phase, meant that they did not need to overcome company cultural issues, but they learnt that they needed to recruit staff that had the ability to fit in with the flexibility required at early stages of growth and company development. Entrepreneurial learning facilitated a willingness to plough back profits into investment in capacity. For example, the comments from a respondent from case \#12 are illustrative of this willingness:

\footnotetext{
“The company probably was never running at capacity and still isn't running at capacity today only because we've brought more equipment but the company has grown, turnover has grown, the number of staff has grown, the business has probably grown quite a bit over the last three years because we've invested a lot back into the business." \#12
}

However, this willingness to reinvest was accompanied by resourcefulness and ingenuity. For example, with case \#12, the company had to make the equipment work, not in their premises, but to be mobile and operate in different locations. This illustrated the learning process that is often typical of entrepreneurial learning: experiential learning or learning 
by 'trial and error', as identified in our literature review, but also entrepreneurs required the capability and ingenuity to achieve successful innovation.

\begin{abstract}
"The machine that we have built is capacity wise five times faster than anything that we've got so it's a large capacity operation and the beauty of going somewhere to do it was obviously we were constrained on size and volume and building size here, but more importantly the idea was to go to the North Island because all our by product from our production currently gets shipped up there anyway. There are some advantages, size of the operation, speed the ability to process quickly and also where we can do it from. In the event this place burnt down tomorrow we would still be up and running, so there's lot of advantages to having it and we have found it very handy lately when we've had some really big orders we've got to produce we can just crank it up and get them out in a week which whereas our existing facility it would take us a month to do it." \#12
\end{abstract}

Similar to case \#12, case \#28, a long established family industrial engineering business, had used their entrepreneurial learning, knowledge and resourcefulness to create a mobile demonstration trailer unit that they could take on site to demonstrate to potential buyers such as farmers and small food and beverage manufacturers. The respondent commented on some of the advantages of this.

\begin{abstract}
"We not only get to see the managing director and the production guy, we get to see the chief engineer, we also get to see the apprentice because they'll drag the apprentice out, he might be told we need you to go and sort that thing out on that machine down there, he'll come and say remember that thing on that trailer I saw a few weeks back, he says that's what I need on that machine, whereas we might not have got that sort of enquiry, and that apprentice or the young engineer or whatever who never gets to see our technology, all of a sudden he's getting to see that and he can relate it to what he requires in his work and hopefully he gets into a position of power one day and decision making, he might remember us. We can start to build that relationship.” \#28
\end{abstract}

\title{
6.2 Innovation: entrepreneurial learning and strategy
}

Entrepreneurial learning, as indicated in our theoretical framework, is critical for empowering TBSFs to translate innovation into changed entrepreneurial behaviour and strategy. Not all our interviews were necessarily with the founding entrepreneur or CEO, but were always with a key manager from the entrepreneurial team (see Table 1).

Entrepreneurial learning had a key role to play in innovation and subsequent entrepreneurial behaviour and strategy. The lessons learned ranged from those issues concerned with just being in business to the more technical issues arising from developing technology and the commercialisation of the NPD process. It is the ability to absorb lessons from experience which is the heart of experiential entrepreneurial learning (as reported in our literature review), in turn this builds capability in TBSFs. Examples of entrepreneurial learning from being in business are illustrated from case \#14, where the founding entrepreneur referred to 'hard lessons', that "you can't learn from textbooks". They had then changed behaviour and strategy as a result of the way that new projects were dealt with for clients. For example, the entrepreneur from case \#13 commented on learning from being in business, having been a farmer.

"So you get more canny, so now when people phone me up and they've got this idea they want us to develop something for them or whatever, I mean I will just think of a number, I'll just say yep we could undertake a feasibility study for 


\begin{abstract}
that, or we could develop a rough prototype, or it just cobble together some bits and pieces, it's going to cost you 10 grand. If they can't find 10 grand, then they are not serious you see." \#14

“Just relationships and how business relationships work. I mean I've been born and bred on a farm and probably consider myself as a farmer so coming from that world into a business world is quite a contrast and I have probably spent the last six or seven years actually learning about business." \#13
\end{abstract}

Entrepreneurial learning from the process of developing products was more commonly quoted than entrepreneurial learning from just being in business. We briefly illustrate from case \#16, a company involved in horticulture, exporting new varieties. However, in initial exports all their trees had died. The entrepreneur commented on the learning process.

"So we had to go through quite a learning process in terms of the background to understand what happened and what we have to change and going forward what did we need to do differently, so there was quite a, you know quite a learning process-------It was probably the first time mature trees had been exported, you are talking like quite large trees, the first lot died.---- It all came down to probably the fact that leading up to this they hadn't been maintained particularly well." \#16

Indeed examples of 'failed NPD' were quite common and were quoted by our respondents. However, to achieve eventual success, entrepreneurs and the entrepreneurial teams in companies had absorbed lessons, adapted and learned from their experience. The importance of changed behaviour from entrepreneurial learning was mentioned by the entrepreneur from case \#22, in handling new technology in aerial photography.

"I think we've done pretty well, we've done two or three major changes but two of them were the biggest were switching to digital photography, and we hit the ground running with that, and we haven't had any issues, we did the same with the LIDAR system, we knew very little about it and what we did is we set up a structure where we would do the flying, and we'd get trained in capturing and operating the system, and we'd be able to process it to a stage, and then pass it on to some specialists." \#22

Entrepreneurial learning, as represented by organisational learning, was reflected in the need to translate opportunities from innovation as part of TBSFs' strategy. For example, case \#08, concerned with new milking systems for dairy farmers had recently been taken over, but the new manager recognised that they could still add to capability and, hence, strategy

"One of the things I say that small businesses have is some entrepreneurial capability and the ability to be relatively agile, quick and responsive, so it's really important that we maintain that. A key part of what we're doing is taking that whole entrepreneurial capability broader than just in $R \& D$, actually out into sales and marketing and allowing our area sales people also to be creative and flexible and entrepreneurial in how they develop their customer relationships, that's a big part of our culture." \#08

\title{
6.3 Innovation: entrepreneurial learning from networks
}

Previous research has indicated that networks and the concept of proximity or 'closeness' is important for entrepreneurial learning and the process of innovation. Membership of 
strategic networks was important for all of our TBSF agri-business companies, for sharing information, knowledge and for forming more strategic partnerships. This can be illustrated with the comments of the founding entrepreneur from case \#05, a company that is a provider of dedicated software for the farming and related sectors. In this case, a woman founder who was a member of a group of women technology-based company founders. Although the network was relatively recently formed, membership was beginning to yield a number of benefits for entrepreneurial learning.

\begin{abstract}
"You know I belong to group of women founders of tech businesses and so within that group we ----you know somebody knows a developer whose available, or they have done some contract work for them, and they will tend to be smaller business so there is that sort of sharing of resources and knowledge and there's probably all sorts of little pockets like that----, it's been going for about six months and it's been certainly clear as with the more times we meet and talk about things, is the experiences and the challenges are different for women and when you get together as a group, a group of women actually exchange information in quite a different way than a mixed group." \#05
\end{abstract}

In the relevant literature, there is often an assumption that TBSFs' strategic networks will be global in nature, yet local networks, with a small number of exceptions, were found to be more important for entrepreneurial learning. For example, the entrepreneur from case $\# 13$, a provider of technology-based services to the farming sector, commented on how his local knowledge and networks had enabled the development of the company.

"I guess I have been involved in the industry for 10 or 12 years, it's just utilisation of those networks I guess --- so some people probably see the business and think that it's had huge growth and it's accelerated growth, but it's a result of 10 or 12 years of networking within the industry and then sort of pulling all that together in a short time which is what we have been able to do." \#13

Similarly with case \#28, a company involved in horticulture, the entrepreneur commented on the importance of local networks.

"The local networks have been very useful from that point of view. But I haven't participated in them, but (name of Director) still swears by them." \#28

Within local networks, the role of early adopters in local markets and local networks was important, not just as a testing ground, but also for demonstration purposes. The comments from the founding entrepreneur with case \#05, indicated that their customers (New Zealand dairy farmers) were early adopters who can provide information to other potential customers.

"The other strategy we have is really trying to use, because the majority of our customers we know are early adopters and are recognised as such in their communities, to actually use them as the centre of the sale and to actually focus their bits on working out from there because farmers sell to farmers, so they like to be able to go and talk to someone who has got it." \#05

Global networks can, for some TBSFs, be more important than local networks, implying proximity, in other dimensions, such as organisational or industry-based connections. For example, with case \#30, which as mentioned previously, had no sales in New Zealand; maintaining contacts with clients overseas was important and, as the comment illustrates, actually going to see them as well. 


\begin{abstract}
"There's no substitute for going to see your customers and your prospects face to face, so we're at the closest 12 hours, and our European customers we're 24 hours away just to get to them, so when we were building our collagen business we kind of neglected our raw tissue business, and we didn't go and see them for two years, and we wondered why business was shrinking, we just weren't keeping the home fires burning." \#30
\end{abstract}

However, as stated earlier this was an exception, it was local networks and entrepreneurial learning from them over a period of time that was important for the majority of our sample.

\title{
$7 \quad$ Discussion and implications
}

In this section, we return to our theoretical framework and research problem: What are the factors that affect the relationship between entrepreneurial learning and innovation? The relationship is explored through the following sub-themes that follow from the research problem: dynamic capabilities, networks and challenges.

\subsection{Entrepreneurial learning and dynamic capabilities}

Dealing with change in the firm's environment and reconfiguring resources was an important theme in our literature review. Entrepreneurial learning is classically experiential, the TBSF entrepreneur needs to be able to assimilate that experience so that the company can deal with growth that has arisen from new opportunities from innovation. Evidence was presented from two companies (\#9 and \#24) which illustrated that organisational and cultural change was required to maintain growth, reconfiguring the companies' resources. Dealing with change and learning from experience was also illustrated from company \#16 even if it meant learning from failure, the firm needs to have the absorptive capability of learning from failure or mistakes or trial and error which will be an important aspect of learning in TBSFs because of the nature of R\&D and NPD and technological change.

We have seen that entrepreneurial learning has a specific and diverse role in the process of innovation, including the importance of individual experiential learning and organisational learning as may be expected, but also entrepreneurial learning from being in business, from contextual adaptability and building capability to deal with change. We can identify the importance of some factors within these 'sources' of learning, notably the knowledge base brought by the entrepreneur and entrepreneurial team which may be supplemented by feedback and advice from key contacts and relationships with customers, external consultants and competitors. The knowledge base is added to by classic 'trial and error' from experience in the R\&D and prototype phase of the innovation process. Given the role of entrepreneurial learning, innovation is not a smooth linear process, rather it involves making mistakes, going down blind alleys before the building of the firm's knowledge base. The process is affected by a range of factors that are subjective, including the nature of key relationships, the role of early adopters and information and contacts from local networks. 


\subsection{Entrepreneurial learning and networks}

An important theoretical theme that emerged from our literature review was the role of networks. To develop a competitive advantage, theoretically, a TBSF entrepreneur needs to be able to reconfigure resources by accessing knowledge and information from local, regional and global networks. An entrepreneurial learning process is involved over time in this process. Our qualitative evidence illustrated the dynamic nature of learning from networks over time. For example, one company (\#13) indicated that knowledge had been acquired from the relevant sector network over a decade and longer, thus illustrating the theoretical importance of dynamic capabilities, capabilities that will change over time by reconfiguring resources from information gathered from local networks.

Some previous research has indicated that global networks are more important than local networks for TBSFs, however, our qualitative evidence for the majority of our companies suggested to the contrary that local networks were more important including cross-sector networks. Local networks were at least as important as global networks, as a source of knowledge, recruitment and finance. However, global networks were important for a minority of companies, occasionally for recruitment, but also for market knowledge, access to these markets and for feedback.

\subsection{Challenges}

In terms of significant challenges; the most important factor mentioned by our TBSF entrepreneur respondents was obtaining a sufficient skill base to able to build their knowledge base and exploit opportunities from the innovation process. A small number of companies also referred to attitudes and culture within their companies as affecting development, particularly where there was resistance to change. Encouragingly, there was some evidence that companies could successfully raise equity and business angel finance. However, obtaining sufficient external finance was still an issue and most of our sample were either totally self-reliant or had sought and recruited private individuals from their own contacts for external financial investment. It appears that attempts to stimulate business angel networks (BANs) by the Regional Development Agencies are at least partially successful with examples of companies that have benefit from specialised local and regional BANs.

To overcome challenges and the limitations of existing resources, some entrepreneurs were able to make resources stretch further, for example, by bootstrapping, or making resources work in different ways. For example, entrepreneurs relied on their knowledge, experience and learning to make equipment and machinery work in ways that yielded more customers and sales. Examples of this 'bricolage' were provided by companies such as \#12 and \#28 who had found solutions to making machinery work in new applications.

Finally, customers became an important resource for a number of TBSFs. This was evidenced in two ways: First through the use of customers as early adopters, effectively providing a test bed from which entrepreneurs could learn from their experience vicariously adding to TBSFs' dynamic capabilities. Second, through the use of customers in co-creation of the development of new products or changes to products. Such ingenuity enabled entrepreneurs to extend their resource base via working closely with their local customers, reinforcing the importance of local networks. 


\subsection{Implications for the existing literature}

There are a number of implications for the existing literature: First, TBSFs are usually treated as a homogenous group of small companies facing similar issues and having similar characteristics as a stylised fact. These characteristics were discussed in our literature review. This study has demonstrated that even within one sector, the agri-business sector, such a stylised view can be misleading. Our evidence suggests instead that diversity of TBSFs is the dominant theme. Second, TBSFs are viewed as resource constrained, even in resource rich environments, partly because they are seen as facing greater uncertainty. Hence, theoretically, we would expect TBSFs to be particularly resource constrained in a lean contextual environment such as New Zealand. We suggest that in practice, via entrepreneurial learning and dynamic capabilities, TBSF entrepreneurs can employ strategies that can overcome resource constraints and maintain a competitive performance. Third, literature needs to recognise that new practical solutions to resource constraints are being found that are sector specific, these include for example, private equity sector-specific investors that are keen to invest in their own sector. Such investors have emerged through the importance of local networks. Finally, this leads to the implication that local networks are as important for TBSFs as global networks and are particularly important for sharing entrepreneurial learning, knowledge and information.

\subsection{Implications for other sectors}

Our study has implications for TBSFs in other sectors in the New Zealand economy. Faced with resource limitations, entrepreneurs in TBSFs in other sectors can learn from some of the successful strategies employed by entrepreneurs in the agri-business sector. Notably, that entrepreneurial learning is important for dynamic capabilities, the ability to reconfigure and stretch resources and innovating to remain competitive. For example, the tourism sector in New Zealand is well known for containing innovative entrepreneurs that have pioneered areas such as adventure tourism. Such established innovative entrepreneurs have the capability to transfer knowledge through local and sector networks. Such networks have begun to be established in some of New Zealand's tourist centres and they will be important for transferring knowledge, experience and learning and will become a critical resource for new ventures in the tourism and other sectors.

\section{Conclusions}

This paper has examined qualitative evidence on the role of entrepreneurial learning in the innovation process in a specific industrial sector, and in a unique environmental context, that of agri-business TBSFs in New Zealand. We have found that even within this specific sector, TBSFs are characterised by diversity, but our qualitative evidence demonstrated the importance of the role of entrepreneurial learning in the innovation process in all our TBSFs. Learning from experience and the ability to learn lessons were key capabilities for our interview sample. Lessons learned ranged from issues concerned with just being in business to the more technical issues arising from developing technology and the commercialisation of the NPD process. Classical experiential 
entrepreneurial learning ranged from just 'being in business' to trial and error from the R\&D process. Successful innovative development depended on being able to develop resourceful strategies and recognising the need to recruit skilled staff at critical stages.

Resources of TBSFs were enhanced by both bootstrapping and bricolage and, contrary to expectations, New Zealand's relatively secure and stable financial credit institutions, namely the stability of the main commercial banks, did not provide a financial environment that has benefited TBSFs in New Zealand compared to their counterparts in other developed countries.

Our qualitative evidence suggests that local strategic networks are important in the innovation process for TBSFs. Proximity in both geographical and other senses (such as social or industrial) is important for ensuring TBSFs are able to call on sources of information and to have the resources, including the skills base, to implement and apply their R\&D for successful NPD.

A combination of factors affected the process of entrepreneurial learning. These factors include: the knowledge base brought by the entrepreneur and entrepreneurial team; feedback and advice from key contacts and relationships with customers, external consultants and competitors; relationships within networks; the role of early adopters and learning from experience in the $R \& D$ of the innovation process and from being in business. Far from being resource constrained, as we hypothesised in our introduction, we conclude that our sample of TBSFs are remarkably resourceful, ingenious and able to find ways to overcome the constraints of a lean environment through techniques such as bricolage, bootstrapping and utilising the importance of the process of entrepreneurial learning.

\section{References}

Ahn, M.J., Meeks, M., Davenport, S. and Bednarek, R. (2010) 'Exploring technology agglomeration patterns for multinational pharmaceutical and biotechnology firms', Journal of Commercial Biotechnology, Vol. 16, No. 1, pp.17-32.

Alvesson, M. and Skoldberg, K. (2000) Reflexive Methodology: New Vistas for Qualitative Research, Sage, London.

Angel Association (2014) [online] http://www.angelassociation.co.nz (accessed 9 June 2014).

Aslesen, H.W. and Freel, M. (2012) 'Industrial knowledge bases as drivers of open innovation?", Industry and Innovation, Vol. 19, No. 7, pp.563-583.

Audretsch, D., Falck, O. and Heblich, S. (2011) 'Who's got the aces up his sleeve? Functional specialization of cities and entrepreneurship', Annals of Regional Science, Vol. 46, No. 3, pp.621-636.

Babnik, K., Trunk Širca, N., and Dermol, V. (2014) 'Individuals learning in work teams: support to knowledge management initiatives and an important source of organizational learning', in Abrudan, I. (Ed.): Challenges and Innovations in Management and Leadership Proceedings, Social and Behavioral Sciences, Vol. 124, pp.178-185, ISSN 1877-0428, Elsevier, New York.

Barney J (1991) 'Firm resources and sustained competitive advantage', Journal of Management, Vol. 17, No 1, pp.99-120.

Bingham, C.B. and Davis, J.P. (2012) 'Learning sequences: their existence, effect, and evolution', Academy of Management Journal, Vol. 55, No. 3, pp.611-641.

Buchart, R. (1987) A New UK Definition of the High Technology Industries, Economic Trends, February, No. 400, Department of Trade and Industry. 
Cannarella, C. and Piccioni, V. (2010) 'Discouraged entrepreneurship and inhibited innovation in times of crisis and recession: empirical observations in doing business in a rural area in central Italy', International Journal of Rural Management, Vol. 6, No. 2, pp.265-288.

Carpenter, R. and Petersen, B. (2002) 'Capital market imperfections, high-tech investment, and new equity financing', The Economic Journal, Vol. 112, No. 477, pp.54-72.

Chiva, R., Ghauri, P. and Alegre, J. (2014) 'Organizational learning, innovation and internationalization: a complex system model', British Journal of Management, Vol. 25, No. 4, pp.687-705.

Cohen, W.M. and Levinthal, D.A. (1990) 'Absorptive capacity: a new perspective on learning and innovation', Administrative Science Quarterly, Vol. 35, No. 1, pp.128-152.

Colombo, M.G. and Grilli, L. (2010) 'On growth drivers of high-tech start-ups: exploring the role of founders' human capital and venture capital', Journal of Business Venturing, Vol. 25, No. 6, pp.610-626.

Cope, J. (2003) 'Entrepreneurial learning and critical reflection: discontinuous events as triggers for 'higher-level' learning', Management Learning, Vol. 34, pp.429-450.

Cope, J. (2005) 'Toward a dynamic learning perspective of entrepreneurship', Entrepreneurship Theory and Practice, Vol. 29, No. 4, pp.373-397.

Cope, J. (2011) 'Entrepreneurial learning from failure: an interpretative phenomenological analysis', Journal of Business Venturing, Vol. 26, No. 4, pp.604-623.

Corbett, A.C. (2002) 'Recognizing high-tech opportunities: learning and cognitive approaches', Frontiers of Entrepreneurship Research, pp.49-61, Babson College, Massachusetts.

Corliolis Report (2012) Moving to the Centre: The Future of the New Zealand Food Industry, Final Report to the Ministry of Economic Development, Wellington former MED.

Davenport, S. (2005) 'Exploring the role of proximity in SME knowledge acquisition', Research Policy, Vol. 34, No. 5, pp.683-701.

de Backer, K. and Yamano, N. (2012) International Comparative Evidence on Global Value Chains, Working papers, 2012/03, OECD Science, Technology and Industry, OECD Publishing, Paris.

de Massis, A., Minola, T. and Viviani, D. (2012) 'Entrepreneurial learning in Italian high-tech start-ups: an exploratory study', International Journal of Innovation and Learning, Vol. 11, No. 1, pp.94-114.

Dermol, V., Trunk Širca, N., Babnik, K. and Breznik, K. (2013) 'Connecting research, higher education and business: implications for innovation', International Journal of Euro-Mediterranean Studies, Vol. 6, No. 1, pp.65-80.

Emerson, R., Fretz, R. and Shaw, L. (1995) Writing Ethnographic Fieldnotes, University of Chicago Press, Chicago, IL.

Federick, H. and Monsen, E. (2011) 'New Zealand's perfect storm of entrepreneurship and economic development', Small Business Economics, Vol. 37, No. 2, pp.187-204.

Gartner, W. and Birley, S. (2002) 'Introduction to the special issue on qualitative methods in entrepreneurship research', Journal of Business Venturing, Vol. 17, No. 5, pp.387-395.

Geertz, C. (1973) The Interpretation of Cultures, Basic Books, New York.

Gellyneck, X., Vermeire, B. and Viaene, J. (2007) 'Innovation in food firms: contribution of regional networks within the international business context', Entrepreneurship and Regional Development, Vol. 19, No. 3, pp.209-226.

Glaeser, E.L., Rosenthal, S.S. and Strange, W.C. (2010) 'Urban economics and entrepreneurship', Journal of Urban Economics, Vol. 67, No. 1, pp.1-14.

Helsley, R.W. and Strange, W.C. (2011) 'Entrepreneurs and cities: complexity, thickness and balance', Regional Science and Urban Economics, Vol. 41, No. 6, pp.550-559.

Jack, S. (2005) 'The role, use and activation of strong and weak network ties: a qualitative analysis', Journal of Management Studies, Vol. 42, No. 6, pp.1233-1259. 
Jones, R. and Parry, S. (2011) 'Business support for new technology-based firms: a study of entrepreneurs in North Wales', International Journal of Entrepreneurial Behaviour and Research, Vol. 17, No. 6, pp.645-662.

Kalantaridis, C. (2006) 'A study into the localisation of rural businesses in five European countries', European Planning Studies, Vol. 14, No. 1, pp.61-78, DOI: $10.1080=09654310500339133$.

Key, J. (2010) Pre-Budget Announcement [online] http://www.beehive.govt.nz (accessed 11 May 2010).

Mason, C. and Brown, R. (2013) 'Creating good public policy to support high-growth firms', Small Business Economics, Vol. 40, No. 2, pp.211-225.

McKeever, E., Jack, S. and Anderson, A. (2015) 'Embedded entrepreneurship in the creative re-construction of place', Journal of Business Venturing, Vol. 30, No. 1, pp.50-65.

Miles, M.B. and Huberman, M. (1994) Qualitative Data Analysis, Thousand Oaks, Sage.

Minister Bill English (2016) 2016 Budget Statement, New Zealand Government, Beehive, Wellington.

Ministry of Economic Development (2010) Management Matters in New Zealand - How Does Manufacturing Measure Up? Findings from the New Zealand Practices and Productivity Global Benchmarking Project, Ministry of Economic Development, Wellington.

Morris, M.H., Kuratko, D.F., Schindehutte, M. and Spivack, A.J. (2012) 'Framing the entrepreneurial experience', Entrepreneurship Theory and Practice, Vol. 36, No. 1, pp.11-40.

Newey, L.R. and Zahra, S.A. (2009) 'The evolving firm: how dynamic and operating capabilities interact to enable entrepreneurship', British Journal of Management, Vol. 20, No. s1, pp.81-100.

North, D., Baldock, R. and Ullah, F. (2013) 'Funding the growth of UK technology-based small firms since the financial crash: are there breakages in the finance escalator', Venture Capital, Vol. 15, No. 3, pp.237-260.

NZVCA (2014) [online] http://www.nzvca.co.nz (accessed 9 June 2014).

OECD (2007) OECD Reviews of Innovation and Policy: New Zealand, OECD, Paris.

Patton, M. (2002) Qualitative Evaluation and Research Methods, Sage, London.

Politis, D. (2005) 'The process of entrepreneurial learning: a conceptual framework', Entrepreneurship Theory and Practice, Vol. 29, No. 4, pp.399-424.

Politis, D. and Gabrielsson, J. (2015) 'Modes of learning and entrepreneurial knowledge', International Journal of Innovation and Learning, Vol. 18, No. 1, pp.101-122.

Rae, D. and Carswell, M. (2001) 'Towards a conceptual understanding of entrepreneurial learning', Journal of Small Business and Enterprise Development, Vol. 8, No. 2, pp.150-158.

Revest, V. and Sapio, S. (2010) Sources of Finance for Technology-Based Small Firms: A Review of the Empirical Evidence, FINNOV project document, European Union, Brussels.

Rinnie, T.A. and Fairweather, J. (2011) An International Comparison of Models of Innovation and Their Implications for New Zealand, Research Report No. 323, August, Lincoln University, Canterbury.

Rudberg, M. (2004) 'Linking competitive priorities and manufacturing networks: a manufacturing strategy perspective', International Journal of Manufacturing Technology and Management, Vol. 6, Nos. 1-2, pp.55-80

Shangqin, H., McCann, P. and Oxley, L. (2009) Innovation in New Zealand: Issues of Firm Size, Local Market Size and Economic Geography, Working paper, Department of Economics, University of Canterbury, Christchurch.

Sitko-Lutek, A. and Jakubiak, M. (2016) 'Skills and learning styles of innovative companies' employees', International Journal of Management, Knowledge and Learning, Vol. 5, No. 2, pp.189-200.

Statistics New Zealand (2013) Research and Development Survey: 2012, Wellington Statistics, New Zealand. 
Svensson, P., Klofsten, M. and Etzkowitz, H. (2012) 'An entrepreneurial university strategy for renewing a declining industrial city: the Norrkőping way', European Planning Studies, Vol. 20, No. 4, pp.505-525.

Teece, D.J. (2007) 'Explicating dynamic capabilities: the nature and microfoundations of (sustainable) enterprise performance', Strategic Management Journal, Vol. 28, No. 13, pp.1319-1350.

Teece, D.J. and Pisano, G. (1994) 'The dynamic capabilities of firms: an introduction', Industrial and Corporate Change, Vol. 3, No. 3, pp.537-556.

The Treasury (New Zealand) (2010) The Economy of New Zealand: Overview [online] http://www.treasury.govt.nz/economy/overview/2010/04.htm (accessed 28 March 2011).

Thorpe, R., Gold, J., Holt, R. and Clarke, J. (2006) 'Immaturity: the constraining of entrepreneurship', International Small Business Journal, Vol. 24, No. 3, pp.232-252.

Virkkala, S. (2007) 'Innovation and networking in peripheral areas - a case study of emergence and change in rural manufacturing', European Planning Studies, Vol. 15, No. 4, pp.511-529.

Wang, C.L. and Chugh, H. (2014) 'Entrepreneurial learning: past research and future challenges', International Journal of Management Reviews, Vol. 16, No. 1, pp.24-61.

Wang, K.Y., Hermens, A, Huang, K-P. and Chelliah, J. (2015) 'Entrepreneurial orientation and organizational learning on SMEs' innovation', The International Journal of Organisational Innovation, Vol. 7, No. 4, pp.71-81.

World Bank (2015) Doing Business 2016, The World Bank, Washington, DC.

Zahra, S. and Wright, M. (2011) 'Entrepreneurship's next act', Academy of Management Perspectives, Vol. 25, No. 4, pp.67-83.

Zahra, S.A. and George, G. (2002) 'Absorptive capacity: a review, reconceptualisation and extension’, Academy of Management Review, Vol. 27, No. 2, pp.185-203.

\section{Notes}

1 We use a broad definition of the agri-business sector which includes food, fibre, forestry and related areas of production.

2 As an economy in which to start a business, New Zealand does even better being ranked as the easiest nation in which to start a new business (World Bank, 2015).

3 This is supported by the World Economic Forum's Global Competitiveness Index which indicates that New Zealand has improved to 20th place overall for 2009, but still performs lower on business sophistication and innovation (36th).

4 Callaghan Innovation absorbed the former commercialisation agency, Industrial Research Limited.

5 The 30 firms have been selected from a programme of 34 interviews with respondent companies, four companies have been excluded since they did not satisfy our criteria for being technology-based.

6 This illustrates the difficulty of applying terms such as 'early stage and 'mature' to TBSFs as their stages of development can differ and are not necessarily correlated with the age of the business. 